\title{
DETERMINANTS OF THE SUCCESS \\ OF THE PROJECT „IMPLEMENTATION \\ OF CSR STRATEGY" IMPLEMENTED \\ IN A MICROENTERPRISE - CASE STUDY
}

\author{
RAFAŁ SZYMAŃSKI \\ University of Szczecin, Faculty of Management and Economics of Services, POLAND \\ e-mail: rafal.szymanski@wzieu.pl
}

RECEIVED
ACCEPTED
JEL
CLASSIFICATION

KEYWORDS

ABSTRACT
18 January 2018

2 September 2018

$\mathrm{M} 11, \mathrm{M} 14, \mathrm{M} 15$

CSR, management, strategy, microenterprise, rural areas

The aim of the article was to collect the most important factors that had an impact on achieving success in implementing the CSR strategy in a microenterprise. The author discussed the most important concepts related to the CSR strategy. The article also presents the specificity of the microenterprise operating in the rural area, including the barriers encountered and the benefits. Based on the research and analysis carried out, the article lists the main factors that have influenced the successful implementation of the CSR strategy in this company. The analysis of this implementation and its implications can constitute a set of good practices for managers who will implement CSR projects, especially in rural areas. The experience gained in the described implementation also shows how the stakeholders react to initiatives in the area of social responsibility.

\section{Introduction}

The project managers and organization managers are most often expected to achieve a success in the economic dimension (Hong, Kubik, Scheinkman, 2012, p. 3). Only few enterprises can afford a wider perspective: achieving economic success through sustainable social and environmental development. From the manager's point of view, determinants that influence the final project's success, including - but not limited to - economic 
success, expected by the company's shareholders, should be considered particularly interesting. The main research goal of this article is to collect the most important factors that influenced the achievement of success, defined by the researched company, in the implementation of the CSR (corporate social responsibility) strategy in microenterprise X. Prior to the research, the research question was formulated: "If the process of communication between stakeholders is properly taken care of before and during the project implementation, then will the success of the project be greater and factors influencing its achievement easier to identify?". The research was conducted among the management, employees and stakeholders of the research project by means of a research questionnaire supplemented with the analysis of project documentation and direct interview with representatives of the above groups. As part of the case study analysis, a total of 47 questionnaires were collected within 14 days, which after an in-depth study were supplemented with information obtained in direct interviews carried out during the next 3 weeks. The questionnaires contained closed questions with the possibility of choosing several answers, while during the interviews, both closed and open questions were asked.

\section{Project, project success and measurement criteria}

An overview of the project definitions referred to in the literature can be summarized after M. Trocki: these are unique projects of high complexity, determined by the period of their implementation, involving significant but limited resources, implemented by interdisciplinary teams of contractors, which due to high risks require special methods of preparation and implementation. (Trocki, 2012, p. 12). Many definitions of project success can be found in the literature. The simplest way is to describe it as "achieving a successful result of a given undertaking or reaching the intended goal in the field of life, art, science or politics." (Skalik, Strzelczyk, 2013, p. 265). The criteria of success are also often mentioned in the literature. The most frequently quoted criterion is that of the golden triangle (Atkinson, 1999, p. 377). According to this criterion, if the project is completed in the previously planned framework of three parameters, such as cost, time and scope (quality), it can be concluded that success was achieved. The wider approach defines success criteria, providing such parameters as: satisfaction of end users and stakeholders, benefits for stakeholders and organizations, and even benefits for project staff. Interesting criteria for the success of the project are proposed by M. Trocki (Trocki, 2012, pp. 7-23) indicating the purposefulness, feasibility, effectiveness, efficiency and usability. It is also worth mentioning the division of the criteria proposed by, A. Shenhar, O. Levy and D. Dvir, who share the criteria of success in terms of operational, tactical and strategic horizons (Shenhar, Levy, Dvir, 1997, p. 46). The literature review in this respect can be summarized by the model of the "square path" proposed by R. Atkinson (Atkinson, 1999, p. 342). This model defines the components of each path element that translates into the success of the project. Summing up all the definitions cited, one can adopt a definition of success consisting of three main areas: the golden project triangle, benefits for the organization and benefits for stakeholders.

\section{CSR strategy in a microenterprise}

To understand the specifics of the researched implementation, it is important to get acquainted with the most important concepts related to the CSR strategy. Authors dealing with issues related to the concept of "strategy" define it in many ways. Some, such as H.A. Simon, refer to the criterion of time, stating that "a strategy can be called a sequence of decisions defining behavior in certain intervals of time" (Simon, 1976, p. 123). Others, such as M. Moszkowicz, refer to the importance of the mission of the enterprise while defining this concept (Moszkowicz, 
2000, p. 34). Some others, such as G. Johnson, K. Scholes and R. Whittington, in their definitions underline the role of stakeholders (Johnson, Scholes, Whittington, 2010, p. 21).

Analyzing the literature of the subject, one can find various definitions of CSR. They include also those that clearly indicate the strategic nature of this concept. J. Korpus believes that "Corporate social responsibility is an effective management strategy, an innovative way of building a competitive advantage in the market" (Korpus, 2006, p. 61). The document "A renewed EU strategy for 2011-2014 regarding corporate social responsibility" published in 2011 underlines the importance of CSR in strategic terms, indicating that "a strategic approach to CSR is increasingly important for the competitiveness of enterprises." (European Commission, 2011). According to J. Adamczyk, the CSR strategy is "comprehensive, formulated and programmed activities, covering relations not only with key stakeholders, such as clients, owners, employees, business partners, but also with social organizations, media, authorities, local and global community" (Adamczyk, 2009, p. 233).

All these definitions apply to all enterprises, without differentiating them due to their size, organizational structure and competitive potential. Theoretical considerations on CSR strategies actually enable such unification, however, economic practice often enforces a more individual approach. Not every microenterprise will be able to use such a broad approach as a medium-sized enterprise. Not every small company will decide to implement the strategy in all areas in which the large enterprise will do it. It will result from both the complexity of the relationship with the environment, the diversity of stakeholders, but also from the financial and organizational possibilities. In organizations, very often the pressure is growing to treat CSR as one of the areas of commercial activity and to expect business results from this initiative (Karim, Rangan, Chase, 2015, p. 56).

The approach adopted by $X$ in the implementation of the CSR strategy resulted precisely from the abovementioned factors. Relations with suppliers and recipients, including the microenterprise, were not different from other companies involved in the production of steel constructions and metal processing, while relations with the closest social environment required a special approach when defining CSR strategies. They were mainly derived from the fact that the company was based in a rural area (in accordance with the definition of rural areas adopted for the needs of the Rural Development Program for the years 2007-2013) and most of its employees came from this area (MRiRW, 2010).

\section{The specificity of a company operating in a rural area}

As J. Gonzalez-Benito and Ó. Gonzalez-Benito observed, the effects of the implementation are undoubtedly also influenced by the specificity of microenterprises (Gonzalez-Benito, Gonzalez-Benito, 2006, p. 91). Another factor specific to the analyzed implementation is related to the functioning of this company in the rural area. This is connected with specific barriers encountered by project managers as well as with some benefits. Company $\mathrm{X}$, at the moment of starting the implementation of the project "Implementation of the CSR strategy" belonged to the group of microenterprises. The location of activities in the rural area was an additional challenge in the implementation. An in-depth analysis of stakeholders indicated that residents of the village in which the company had its headquarters were of key importance for the further implementation of the CSR strategy. The fact that most of the company's staff were also residents of this village had a great impact. On the one hand, it facilitated reaching a wider group of the local community, as Scott R. also wrote, and on the other hand it increased the pressure on the implementation team (Scott, 2016). 
The company was exposed to a number of negative factors affecting its functioning: from "denunciations" about alleged environmental anomalies - which resulted in frequent inspections of the offices responsible, through the reluctance of property owners bordering the company - which hindered development opportunities, ending with the general negative image which, among other things, made it difficult to acquire a new staff. All these barriers have been analyzed and described prior to the implementation of the project. The summary is presented in Table 1.

Table 1. Barriers in the company $X$ activity

\begin{tabular}{lll}
\hline \multicolumn{1}{c}{ Barrier/problem issue } & \multicolumn{1}{c}{ CSR area } & \multicolumn{1}{c}{ Stakeholders concerned } \\
\hline $\begin{array}{l}\text { Inefficient use of human resources and production capacity of highly } \\
\text { efficient devices purchased under previously implemented projects }\end{array}$ & $\begin{array}{l}\text { employees, environmental } \\
\text { protection }\end{array}$ & employees, owner, recipients, clients \\
\hline $\begin{array}{l}\text { Low awareness of employees regarding the impact of their partial } \\
\text { activities on environmental protection in a broader sense }\end{array}$ & $\begin{array}{l}\text { employees, environmental } \\
\text { protection }\end{array}$ & $\begin{array}{l}\text { employees, owner, local community, offices, } \\
\text { state institutions, recipients, clients }\end{array}$ \\
\hline $\begin{array}{l}\text { Low awareness of suppliers and customers regarding their impact } \\
\text { on the company's operations and indirect impact on the natural } \\
\text { environment and the social environment }\end{array}$ & $\begin{array}{l}\text { external stakeholders, } \\
\text { environmental protection }\end{array}$ & $\begin{array}{l}\text { employees, owner, local community, offices, } \\
\text { state institutions, recipients, clients }\end{array}$ \\
\hline Too low activity of the company in voluntary local activities & $\begin{array}{l}\text { external stakeholders, } \\
\text { employees }\end{array}$ & employees, owner, local community \\
\hline
\end{tabular}

Source: own elaboration.

Following the analysis, these barriers were assigned to one or several CSR areas and it was indicated which stakeholder groups are directly affected. The areas of CSR were defined based on the literature analysis carried out, including the theory of R. Spaemann, who brought social responsibility in business to five tasks (Filek, 1999, p. 126). On this basis, taking into account design guidelines, it was assumed that the CSR areas which will be managed by the company are: employees (including the owner), external stakeholders (suppliers, recipients, local community, local business, offices, business environment institutions) and environmental protection (primarily local, but also in the global scale by reducing the consumption of materials, energy, etc.). The owner of the company also agreed to the definition proposed by the project manager, which read: "As for the owner, CSR is identified with such a business run that will firstly take care about the company's employees and their families (this also applies to the owner) and then about the social area and environment located in the village of $X$ and the commune of $Y$ " (Szymański, 2013, p. 38). This definition was in line with the ISO 26000 norm (in force at the time of implementation) (PKN, 2012). At the same time, in the definition adopted for the implementation of this project, the importance of two groups of stakeholders, i.e. employees and the local community, was emphasized, which resulted both from the specific nature of the company's operations in the rural area and from the analyzes described in more detail below.

\section{Determinants of the project's success}

The research questionnaire covered a total of 47 people: 3 from the top management, 6 full-time employees, 5 seasonal employees and 33 non-company employees (suppliers, recipients, residents of villages and local officials). The research questionnaire was asked, inter alia, to indicate the main reasons for the success (or failure) of the project. The four most frequently mentioned by the respondents answers were selected. Next, representatives of the top management were asked to describe the actions taken in relation to the most frequently indicated reasons for success. 
Table 2. The most frequent reasons for the success of the project - quantitative results of the research questionnaire

\begin{tabular}{lccc}
\hline \multicolumn{1}{c}{$\begin{array}{c}\text { Most often indicated } \\
\text { reasons for the project's success }\end{array}$} & \multicolumn{2}{c}{$\begin{array}{c}\text { Number of indications among respondents, } \\
\text { divided into groups }\end{array}$} \\
\cline { 2 - 4 } & management & employees & external stakeholders \\
\hline Dialogue with stakeholders & 3 & 10 & 28 \\
Analysis of stakeholders & 3 & 9 & 26 \\
Defining strategic goals & 3 & 8 & 23 \\
Establishing management procedures & 3 & 11 & 12 \\
\hline
\end{tabular}

Source: own elaboration.

It turned out that based on the CSR definitions adopted for the project implementation and the actions undertaken related to the definition of implementation barriers, a decision was made to analyze the stakeholders before proceeding with the project. The results of this analysis together with the division criteria used are presented in Table 2.

Table 3. Stakeholders of the company $X$

\begin{tabular}{lcl}
\hline Division criterion & Distinguished groups & \multicolumn{1}{c}{ Name of stakeholder } \\
\hline \multirow{2}{*}{ Meaning, significance } & primary & local community, employees, suppliers \\
& secondary & competitors, clients, offices, business environment institutions \\
\hline \multirow{2}{*}{ Origin } & internal & employees, local community, owner \\
& external & local community, suppliers, clients \\
\hline
\end{tabular}

Source: own elaboration.

This division was consistent with the systematization presented by P. Wołczek, A. Skrzypek and R. Szymański, which divides the stakeholders into groups based on various criteria: significance, voluntariness, origin, market, urgency and the specific nature of the relationship between the environment and the enterprise (Wołczek, Skrzypek, Szymański, 2016, p. 60). The decision to conduct such an analysis was one of the reasons indicated for the success of the project implementation.

Another success of the project was the decision to enter into a dialogue with these stakeholder groups. Specific guidelines have been adopted on how to conduct this dialogue. It was also established that during meetings with stakeholders, a moderated discussion about relevant expectations and stakeholder assessments about the most important impact areas of the company will start, which in turn will help identify both the most active stakeholders and areas of CSR that require further in-depth analysis.

The strategic goals set by the company also contributed to the project's final success. These goals have been approved by the owner and the management team. At the same time, internal and external consultations were recommended for acceptance by other stakeholders.

The determinant of the success of this project should also include the fact that the outline of CSR management procedures was defined at the stage of strategy creation. The persons directly responsible for the implementation of CSR in the company were identified. In order to effectively monitor the implementation of the sustainable development policy in the company, key sustainability indicators were also set up, informing the management about 
the status and level of achievement of the assumed goals. The principle was also adopted that the communication of these results to both internal and external group of stakeholders will be carried out on an ongoing basis. Appropriate communication with stakeholders is one of the basic principles that should guide CSR managers (Du, Bhattacharya, Sen, 2011, p. 1541).

\section{Conclusions}

The conclusions drawn from the research and analyzes carried out for the purposes of this article indicate that there may be many factors of project success, but in a specific environment, which is the rural area, the main ones include a detailed analysis of stakeholders and a well-thought-out, consistently implemented communication strategy with them. The surveyed company $X$ completed its implemented project in the area of CSR, thanks to the use of these two activities. It carried out a multi-faceted analysis of the relationships it had with both employees, suppliers, recipients, cooperators, clients, offices, but also with the local community. On this basis, it adopted specific rules for communicating with these groups and consistently implemented them. Such an approach meant that project risks, which are most often caused by people, were recognized at an early stage of their fulfillment, which allowed the company to take pre-emptive actions quickly or to prepare to minimize their consequences if they were not avoided. Following the good practice manuals, this microenterprise operating in the rural area is an interesting example of the manager's skillful finding of the factors that were crucial for the final success of the CSR strategy implementation project.

\section{References}

Adamczyk, J. (2009). Społeczna odpowiedzialność przedsiębiorstw. Warszawa: PWE.

Atkinson, R. (1999). Project management: cost, time and quality, two best guesses and a phenomenon, it's time to accept other success criteria. International Journal of Project Management, 6 (17), 337-342.

Du, S., Bhattacharya, C., Sen, S. (2011). Corporate social responsibility and competitive advantage: Overcoming the trust barrier. Management Science, 57 (9), 1528-1545.

Filek, J. (1999). Społeczna odpowiedzialność przedsiębiorstwa. In: W. Gasparski, A. Lewicka-Strzałecka, D. Miller (eds.), Etyka biznesu i gospodarki i zarządzania. Łódź: Wydawnictwo Wyższej Szkoły Humanistyczno-Ekonomicznej.

Gonzalez-Benito, J., Gonzalez-Benito, Ó. (2006). A review of determinant factors of environmental proactivity. Business Strategy and the Environment, 15 (2), 87-102.

Hong, H., Kubik, J.D., Scheinkman, J.A. (2012). Financial constraints on corporate goodness. National Bureau of Economic Research, 12, 1-44.

Johnson, G., Scholes, K., Whittington, R. (2010). Podstawy strategii. Warszawa: PWE.

Karim, S., Chase, L., Rangan, K. (2015). Czym naprawdę jest CSR. Harvard Business Review, 151, 56.

Komisja Europejska (2011). Odnowiona strategia UE na lata 2011-2014 dotycząca społecznej odpowiedzialności przedsiębiorstw, KOM (2011) 681 wersja ostateczna, Bruksela.

Korpus, J. (2006). Społeczna odpowiedzialność w obszarze kształtowania środowiska pracy. Warszawa: Placet.

Koźmiński, A.K. (ed.) (1995). Zarządzanie. Teoria i praktyka. Warszawa: PWN.

Ministerstwo Rolnictwa i Rozwoju Wsi (2010). Program Rozwoju Obszarów Wiejskich na lata 2007-2013, Warszawa.

Moszkowicz, M. (2000). Strategia przedsiębiorstwa okresu przemian. Warszawa: PWE.

PKN (2012). Retrieved from: www.pkn.pl/iso-26000.

Polska Agencja Rozwoju Przedsiębiorczości (2013). Wytyczne dla wnioskodawców ubiegających się o udzielenie wsparcia na wdrożenie społecznej odpowiedzialności biznesu (CSR) w konkursie ogłoszonym w ramach projektu Zwiększenie konkurencyjności regionów poprzez społeczną odpowiedzialność biznesu (CSR). Retrieved from: http://csr.parp.gov.pl/files/74/455/16070.pdf. 
Scott, R. (2016). Are You Defining CSR Success All Wrong. The Forbes. Retrieved from: www.forbes.com/sites/causeintegration/ 2016/04/06/are-you-defining-csr-success-all-wrong/2/\#279419f9703b.

Shenhar, A., Levy, O., Dvir, D. (1997). Mapping the Dimensions of Project Success. Project Management Journal, 28 (2), 2-10.

Simon, H.A. (1976). Działanie administracji. Warszawa: PWN.

Skalik, J., Strzelczyk, A. (2013). Kluczowe czynniki sukcesu w zarządzaniu projektami informatycznymi. Journal of Management and Finance, 1 (4), 265-265.

Szymański, R. (2013). Opracowanie strategii Społecznej Odpowiedzialności Biznesu w firmie X. Szczecin.

Trocki, M. (ed.) (2012). Nowoczesne zarządzanie projektami. Warszawa: PWE.

Trocki, M. (2012). Kompleksowa ocena projektów. Studia i Prace Kolegium Zarządzania i Finansów. Zeszyty Naukowe SGH, 113, 7-23. UE (2014). Rozporządzenie Komisji (UE) nr 651/2014 z dnia 17 czerwca 2014 r. uznające niektóre rodzaje pomocy za zgodne z rynkiem wewnętrznym w zastosowaniu art. 107 i 108 Traktatu, Dz.Urz. UE L 187/1 26.06.2014.

Wołczek, P., Skrzypek, A., Szymański, R. (2016). Strategiczny CSR. Warszawa: Texter.

Cite this article aS: Szymański, R. (2018). Determinants of the success of the project "Implementation of CSR strategy" implemented in a microenterprise - case study. European Journal of Service Management, 3 (27/2), 453-459. DOI: 10.18276/ejsm.2018.27/2-55. 